The Persuasive Force of Demanding

\begin{abstract}
Demanding is a fundamental rhetorical strategy for marginalized groups, but recent rhetorical theories of demanding have not explained how speakers can design demands to influence addressees to accede. Psychoanalytic and decolonial theories have identified constitutive functions, but have not explained how speakers can design demands that pressure addressees to accede. Speech act theories have explained specific kinds of demands but have not synthesized insights into a model of demanding generally. We draw on normative pragmatic theory to argue that speakers design demands that generate persuasive force by openly making visible their intent to influence addressees to accede and bringing to bear a reciprocal obligation for themselves and addressees to live up to the norm of "right makes might."
\end{abstract}

Keywords: demanding, argumentation theory, normative pragmatic theory, speech act theory, Paul Grice 


\section{The Persuasive Force of Demanding}

\section{Introduction}

A paradigm case of demanding involves making utterances designed to influence addressees to accede. ${ }^{1}$ It would be incoherent to say, "I demand you to $x$, but I am not saying that you ought to $x$," or "I demand you to $x$, although I am fully aware that you cannot $x$." The extraordinary nature of demanding may be gleaned from anomalous utterances such as: "Employees may demand time off by notifying scheduling managers at least one month in advance," and "Faculty members may demand an extension of the tenure clock in writing to the provost." Demanding is less anomalous in protest rhetoric and in fact an important strategy for marginalized groups who "are criticized for not handling conflicts and controversies through normal, proper channels and procedures, even when those channels and procedures are systematically denied them" (Stewart, Smith, and Denton 2007, 8; see also Bowers et al. 2010). Whence the persuasive force of demanding?

Three recent rhetorical theories of demanding have not addressed this fundamental question. First, psychoanalytic accounts of demanding (e.g., Lundberg 2012a, 2012b) have explained constitutive functions of demands, describing demanding as a trope that shores up subject identity and gives retroactive coherence to subjects. Second, decolonial accounts of demanding (e.g., Enck-Wanzer 2006; Wanzer-Serrano 2015) have also focused primarily on constitutive functions. Third, rhetorical accounts based in speech act theory (e.g., Burgess 2013, 2015) have described features of specific kinds of demands - demands for apology and for recognition—but have not outlined a coherent account of demanding generally.

We submit a rhetorical theory of demanding that describes its normative structure, and we show that the theory accounts for design strategies used in a case of successful demanding. 
Drawing on normative pragmatic theory (e.g., Goodwin 2001, 2007, 2011; Innocenti 2011; Innocenti and Miller 2016; Jacobs 2000, 2016; Kauffeld 1998, 2001, 2009; van Eemeren et al. 2014), we argue that the normative structure of demanding involves speakers (1) openly making visible (a) their intent to influence addressees to accede, thereby (b) incurring an obligation to live up to a norm captured by the aphorism "right makes might." (2) The obligation is reciprocal; both speakers and addressees can hold each other accountable for recognizing and living up to the norm. (3) As a result, demanding creates two reasons for addressees to accede. (a) First, addressees can reason that speakers would not risk criticism for failing to live up to the norm unless they can show they are in the right and counting on rightness, in contrast to threats or coercive tactics, to be the source of influence. (b) Second, speakers can reason that addressees will be influenced to accede in order to avoid criticism for failing to live up to the norm-for remaining conspicuously in the wrong or for deploying coercive power to squelch demands.

Our argument proceeds in three parts. First, we review three recent rhetorical theories of demanding to illustrate the needs that our model of the normative structure of demanding meets. Second, we defend the model analytically. Third, we illustrate that it accounts for the design strategies used in a case of actual, successful demanding.

\section{Psychoanalytic theory of demanding}

Since Gregg (1971) published his landmark essay on the ego-function of protest rhetoric, psychoanalytic theories of demanding have explained how demanding shores up demanders' subject identities but not how demanding generates persuasive force for addressees to accede. Practical and intellectual starting points of psychoanalytic theories have lead to accounts featuring subject identity formation. A practical starting point has been cases of demands that on 
face appear to be non-serious in the sense that they are not designed to pressure addressees to accede. Gregg aimed to account for cases involving protestors "moving to a perspective which includes the total social, political, and economic scene," where "demands go beyond the power of the authorities to act; it somehow seems unreasonable to expect the president of a Pennsylvania university to be able to grant amnesty to Bobby Seale” (1971, 73). In addition, Gregg asserted that the "usual" view of rhetorical transactions-which "expects the entreaties, appeals, arguments, and exhortations of those asking for change to speak somehow to the basic reasoning and feeling capacities of those in authority"- does not fit "contemporary public protest": "The escalation of demands, in fact the very couching of wishes in terms of demands, appears to those in positions of power, reacting to the rhetoric, to foreclose meaningful discussion" $(1971,73)$. So Gregg concluded "that the primary appeal of the rhetoric of protest is to the protestors themselves, who feel the need for psychological refurbishing and affirmation," and that "the ego-function of rhetoric has to do with constituting self-hood through expression" $(1971,74)$.

Since that time, rhetorical scholars have developed increasingly sophisticated psychoanalytic theories of demanding. The theories continue to begin with cases of demands that on face do not appear to be serious in the sense that they are designed to pressure addressees to accede. As a consequence, the theories feature subject identity formation and maintenance. They diagnose and address a potential political problem generated just by demanding. On one hand, subjects may demand change in hegemonic structures but, on the other hand, may depend on those very structures in order to claim a marginal subject identity. If addressees accede to subjects' demands, then a measure of subjects' identity as marginalized outsiders collapses. To shore up their marginal identity, demanding subjects become alienated from their desire and 
satisfied just by demanding rather than by actually influencing addressees to accede (Lundberg 2012a, 2012b).

A second starting point of psychoanalytic theories, assumptions about the nature of language, explains why psychoanalytic accounts of demanding feature shoring up subject identity. Following Laclau, psychoanalytic theory has defined the fundamental problem of language as one of "signification" (Lundberg 2012b, 299)—a failure of language to signify "without remainder" (Lundberg 2012a, 3). Rhetoric has been theorized as "the effectivity of trope in the context of failed unicity" (Lundberg 2012a, 47), so use of a trope is "a mode of enjoyment" that subjects "invest in" because it "lends durability to social formations" (Lundberg 2012a, 126). In other words, the "subject identifies with an external image of itself for the sake of providing its practices of subjectivity with a kind of enjoyable retroactive coherence" (Lundberg 2012b, 304). This account features constitutive but not instrumental functions.

In short, psychoanalytic theories have explained how what appears to be non-serious demanding can generate grounds for political action by dint of the subject identities to which demanding gives coherence and durability in the face of the failure of language to signify without remainder. But they have not explained how demands that on face appear to be serious attempts to pressure addressees to accede can reasonably be expected to generate persuasive force.

\section{Decolonial theory of demanding}

Like psychoanalytic theory, decolonial theory (e.g., Enck-Wanzer 2006; Wanzer-Serrano 2015) has foregrounded constitutive functions of demanding. For example, Wanzer-Serrano (2015; Enck-Wanzer 2006) has explained constitutive functions of demands made by the Young 
Lords Organization in the summer of 1969 in the context of the "garbage offensive." Every Sunday members of the Young Lords Organization cleaned up garbage in El Barrio, a predominantly Puerto Rican section of New York City. The Young Lords Organization demanded that the New York City Sanitation Department do its job and collect the garbage. When the Sanitation Department refused, members of the Young Lords Organization and the El Barrio community blocked busy intersections with garbage heaps and, over time, intensified their actions by setting fire to the garbage, overturning cars, and more. Their demand strategy achieved some measure of instrumental success in pressuring the Sanitation Department to pick up the garbage occasionally but not regularly. In his analysis of the garbage offensive, WanzerSerrano has foregrounded the constitutive function of demanding: it was among the acts that "successfully constituted the people and space of El Barrio as potential agents of change" (2015, 124). Likewise, in other work Wanzer-Serrano has theorized constitutive benefits of unsatisfied demands, asserting that a "demand is interesting and important precisely because it is not satisfied - which means that it continues to drive the relation between self and other, thus keeping the processes of identification open or deferred and forming the contingent foundation of a radical democratic politics" (Enck-Wanzer 2011, 63).

Decolonial theory is designed to explain practices that "attempt to delink from modernity/coloniality" (Wanzer-Serrano 2015, 11). Decolonial theorizing does not involve whole cloth rejection of theorizing that reproduces coloniality and proceeds from geographical locations and bodies of "epistemic privilege" (Wanzer-Serrano 2015, 24-25, 86). But decolonial theorizing can "re-accent" (Wanzer-Serrano 2015, 27) Western theorizing so the theorizing speaks from and to the Global South. Significantly, decolonial theorizing involves reading marginalized discourses on their own terms. In what follows, we note in a Western accent three 
significant affinities with normative pragmatic theorizing which, like decolonial theorizing, involves attending to what social actors say and what they say they are doing (e.g., Goodwin 2001; Innocenti and Miller 2016).

First, Wanzer-Serrano (2015) has accounted for the functioning of the garbage offensive by explaining how strategies redesign the scene to produce constitutive outcomes which, in turn, influence action. The insight that social actors communicatively create contexts has enabled scholars to explain how social actors can communicatively design contexts that enable and constrain actions and interactions, creating more favorable conditions or grounds for disputation, deliberation, reflection, and the like (e.g., Aakhus and Laureij 2012; Jackson 1998; Jacobs 2006; Tracy 2012). Wanzer-Serrano has explained how participants in the garbage offensive deployed various rhetorical forms and "fundamentally altered the scene in a manner that allowed for different agents and agencies to emerge" $(2015,141)$.

Second, Wanzer-Serrano (2015) has accounted for the functioning of the garbage offensive in terms of the visibility and accountability that it generated. Comparable to what Asen has described as the "responsibility attribution" function of arguing in "situations in which less powerful actors compel more powerful actors to accept public responsibility for decisions that they have made in restricted deliberative situations" (2005, 119), Wanzer-Serrano (2015) has explained how the Young Lords knew full well that New York City sanitation department officials would not accede to their demands that it do its job and collect garbage in El Barriodemands that on face appeared to be serious because the sanitation department was able and ought to collect garbage in El Barrio — but they made demands anyway in order to display that "the system" was broken. The ongoing presence of garbage in light of the ignored demands made conspicuous "both evidence of the state's disrespectful and malicious attitude toward the 
community and proof of 'the system's' incapability to deal with its own intemperance" (WanzerSerrano 2015,129$)$. The demand strategy in the garbage offensive redesigned a space that enabled the people of El Barrio to hold the sanitation department and broader system accountable for complicity with significant problems and to recognize their own political agency in bringing the problems to light and addressing them.

Third, Wanzer-Serrano (2015) has accounted for a case of successful demanding in terms of pressure to adhere to democratic norms of interaction explicitly brought to bear in a situation. Within the Young Lords Organization, members of the cadre successfully demanded gender equality from members of the Central Committee by using the organization's own democratic procedures. They held a large meeting in which members of the Central Committee were charged, people testified, and a vote was taken to discipline the Central Committee members. Wanzer-Serrano has explained the persuasive force of their actions: "the structural reformulation of the Young Lords was a direct result of the cadre asserting their rights to democratic participation and holding all members accountable to the same rules" $(2015,102)$. As Tracy has suggested, not only the strategy of invoking rules but even the strategy of naming a norm such as "reasonable hostility" $(2012,205)$ makes norms available to social actors to structure interaction. Strategies make visible rules or norms, so enable interactants to hold each other accountable for acting in accord with them.

In sum, although Wanzer-Serrano's theorizing (2015) has featured constitutive functions of demanding, along the way he has accounted for both constitutive and instrumental achievements in ways that align with normative pragmatic accounts. Significantly, both WanzerSerrano (2015) and members of the Young Lords Organization have accounted for the persuasive force of strategies by pointing to the visibility and accountability that strategies 
generate as they change the scene or context. As we will see, that kind of account describes the normative structure of demanding generally.

\section{Speech act theory of demanding}

Speech act theories address the question of how speakers can design demands to pressure addressees to accede. The question is practical, inquiring into how demanding can be designed to do what it is ostensibly designed to do rather than inquiring into other functions demanding may serve. In addition, the question features not referential functions of language but language as action.

Drawing on the fundamental insight of speech act theory that saying something is performative - that in saying something we do something (Austin 1962)—Burgess $(2013,2015)$ has developed accounts of demands for apology and demands for recognition. She has described both kinds of demands as "speech acts" $(2013,352 ; 2015,521)$ : utterances whose power is in "the saying" $(2015,530)$. Rather than attempting to generate a model of demanding generally, her account of the demand for recognition, for example, is part of a broader project to analyze the rhetoricity of law - an "elision [...] repeated in the scholarly critiques that focus on recognition's pathological attachment to identity and/or its inability to challenge structures of power" $(2015,519)$. However, because she begins with a view of language as action, her accounts of demands for apology and for recognition point to the normative structure of demanding generally. In this section we note four key insights of her accounts, and in the following section we synthesize the insights into a coherent model of the normative structure of demanding generally. In doing so we necessarily elide details from her accounts of specific kinds 
of demands, but having a coherent general model of demanding may bring into sharper focus "rhetorical contours" (Burgess 2015, 522, 528) of specific kinds of demands.

First, the fundamental insight of Burgess' analyses, one she shares with Wanzer-Serrano (2015), is that uttering a demand changes the context or, as she has put it, is "an act of rhetorical invention that "makes a scene"” (Burgess 2015, 522), and "constitutes the scene of address in which it operates" (Burgess 2013, 357). For example, Burgess has explained how a demand for recognition "creates the structures in which we might engage the terms of law, expose the conditions in which law's claim of recognition is made, and unsettle law's place as a frame" $(2015,532)$.

Second, Burgess' analyses have suggested the need to design a demand that is recognized as a demand. This means, first, a speaker must actually utter the demand. As Burgess has put it, "both the contingency and the power of a demand for recognition is that it depends on the recognizability of the speech act itself' $(2015,530)$. In addition, a speaker must openly demand so, on one hand, she cannot plausibly deny that she is demanding and, on the other hand, addressees cannot plausibly deny recognizing that she is demanding. The demand must be "transparent" (Burgess 2015, 527) and "heard as a demand" (Burgess 2015, 528). Burgess has pointed to the need to act openly when she notes how a speaker who demands an apology may respond to the apology: "The success of an apology depends [. . .] on how this apology is 'taken up' and read. Thus the one who demands an apology judges whether the apology meets the conditions of recognizability in the particular context" $(2013,353)$. By openly apologizing, the apologizer constrains the demander of apology from easily, perfunctorily dismissing her utterance as not an apology. 
Third, Burgess' analyses have pointed to the claim to occupy the moral high ground implied just by demanding. For example, by demanding an apology, a speaker "claims the high ground, a position from which he takes authority to pass judgment on [the addressee's] speech and actions" (Burgess 2013, 355). Moreover, Burgess has observed that the point of demanding an apology may be to serve as "a performance of the place (and the power) the speaker claims by virtue of the demand" $(2013,355)$.

Fourth, Burgess' analyses have foregrounded the insight that demanding entails risk. For example, "To demand recognition is to take a risk and to occupy a place from which one might (later) be displaced. It is possible that the other might not hear the demand or understand what the demand means. It is possible that one's demand will be met with doubt. It is possible that one's demand will be read as a joke or a rhetorical question" $(2015,531)$, it "might entail humiliation, injury, violence, and perhaps even death" $(2015,527)$.

In sum, Burgess' $(2013,2015)$ accounts of specific kinds of demands have pointed to features of demanding generally: demanding (1) communicatively changes the context, (2) must be performed openly and recognizably, (3) implies a claim to occupy the high ground, and (4) entails risks. Joined to Wanzer-Serrano's (2015) observation that (5) strategies generate accountability to live up to norms, these insights help to account for why a demander who simply says, "I demand you to $x$ " can reasonably expect just that utterance to influence addressees to accede. In what follows we synthesize these insights into a model of the normative structure of demanding generally.

\section{Normative pragmatic theory of demanding}

\section{Basic normative pragmatic model}


Normative pragmatic theories (e.g., Goodwin 2001, 2007, 2011; Innocenti 2011; Innocenti and Miller 2016; Jacobs 2000, 2016; Kauffeld 1998, 2001, 2009; van Eemeren et al. 2014) have explained why speech acts may reasonably be expected to influence addressees just as the speaker intends. The theories are "normative" because they locate persuasive force in norms that message designs bring to bear in a situation, and "pragmatic" because they account for the persuasive force of actual message designs. In broad outline, the basic normative pragmatic model is: (1) a speaker's utterance makes visible her (a) intent and (b) concomitant obligation to live up to some norms. (2) The visibility of the intent and obligation enable the speaker and addressees to hold each other accountable for living up to the norms. (3) So the utterance changes the context to create two reasons for addressees to be influenced. (a) First, addressees can reason that the speaker would not risk criticism for failing to discharge obligations she has incurred just by saying something unless she can meet them. (b) Second, the speaker can reason that addressees will be influenced in order to avoid criticism for failing to meet the obligations.

Normative pragmatic theories are based on Kauffeld's $(2001,2009)$ work in the philosophy of language, and specifically a Gricean analysis of utterance-meaning. Kauffeld $(2001,2009)$ has used Grice's work to outline the intentions and sub-intentions that account for what it means to seriously say and mean something, and Stampe's work to explain how addressees' recognition of a speaker's intentions gives some reason for them to be influenced. Following Kauffeld $(2001,2009)$, the basic Gricean account of utterance-meaning is that a speaker not only intends her utterance to induce some response in addressees (the primary speaker intention). She also intends that addressees' recognition of both (a) the speaker's primary intention and (b) the speaker's intention for the utterance to induce them to respond gives 
addressees reasons to respond just as she intends. Why? The speaker's efforts to secure addressees' recognition of (a) involve deliberately trying to make her primary intention apparent. The speaker's efforts to secure addressee's recognition of (b) involve openly trying to make (a) apparent. These deliberate, open efforts to induce a response give addressees some reason to respond as the speaker intends, because the speaker incurs obligations for which addressees can hold her accountable.

How are obligations communicatively generated, and why are they potentially effective in securing the speaker's intended response? To address these questions, Kauffeld $(2001,2009)$ has used the work of Dennis Stampe to explain how obligations undertaken and discharged by speakers give some reason for addressees to respond as the speaker intends. This explanation is the linchpin of normative pragmatic accounts of why speakers can reasonably expect their performances of illocutionary speech acts, such as proposing and accusing, to pressure addressees to act as the speaker intends. To illustrate, consider the basic presumption of veracity. When a speaker seriously says and means an utterance, $u$, she incurs an obligation to speak truthfully. The obligation is fundamental because addressees who can easily dismiss a speaker's utterance as untruthful, ignorant, and the like will not experience pressure to be influenced by the utterance. So ordinarily, making an utterance licenses addressees to presume the speaker is speaking truthfully or, put differently, generates a presumption of veracity: addressees can reason that the speaker would not risk criticism for lying, ignorance, and the like unless she had made a responsible effort to ascertain the veracity of her utterance. That presumption is one reason, created just by saying, " $U$," that addressees now have to be influenced by the utterance. Obligations incurred by the speaker just by making an utterance are reciprocal, because their visibility creates a context in which both speaker and addressees can be held accountable for 
living up to them; as speakers ought to speak with veracity, so addressees ought not act with undue skepticism, cantankerousness, and the like. So bringing to bear an obligation to speak truthfully creates a second reason for addressees to be influenced by the utterance: in order to avoid criticism for undue skepticism, cantankerousness, and the like, addressees can acknowledge the veracity of the utterance.

Of course rhetorical influence is not as simple as this account, or any account for that matter, suggests. As Kauffeld has put it, "the presumption of veracity, upon which statements fundamentally depend for their efficacy, does not carry enough practical weight to fulfil[1] the speaker's purpose in the face of doubt, disagreement, evasion, and opposition" $(1998,259$; see also Pinto 2007). Consequently, speakers routinely make special efforts to influence addressees to, say, carefully consider a proposal or accede to a demand — efforts in addition to the basic act of saying, "I propose $x$ " or "I demand you to $x$." In what follows we outline and analytically defend a model of the normative structure of demanding based on just the utterance "I demand you to $x$." In the next section we show how the model accounts for actual message design, or the special communicative efforts that speakers made in a case of successful demanding.

\section{Normative pragmatic model of demanding}

The sine qua non of demanding is openly making visible an intent to influence addressees to accede. Demanding must be recognizable as a demand; it must be serious. It would be incoherent for a speaker to say, "I demand you to $x$, but I do not mean to suggest that you $x$." If a speaker can plausibly deny the intent to influence addressees to accede to a demand, then demanding loses persuasive force because addressees can ignore the utterance with impunity, perhaps dismissing it by saying, "You can't be serious."

Besides an obligation to speak truthfully incurred when speakers make serious utterances, 
what obligations do speakers incur just by demanding? What norms does demanding bring to bear in a situation and oblige speakers and addressees to live up to? As we have noted, demanding is extraordinary; it is a step outside the bounds of propriety and sounds out of place in statements of routine, institutional policies and procedures. This quality indicates another part of the normative structure of demanding: demanding implies that ordinary procedures are not working, so obligates the speaker to be able to show that addressees are procedurally in the wrong. In ordinary circumstances, if an employee said to a scheduling manager that she demands time off, the scheduling manager would just need to direct the speaker to follow protocol and make a request that the scheduling manager may grant. But if the scheduling manager denied the employee's routine request for time off, the decision appeared to be arbitrary, and the manager could not produce good reasons for denying the request, then it may be appropriate for the employee to demand time off. This scenario points to another part of the normative structure of demanding: demanding implies that addressees are substantively in the wrong so obligates the speaker to be able to show just that. It would be incoherent to say, "I demand you to $x$, but I cannot show you why $x$ is the right thing to do."

Unlike routine requesting, demanding may routinely produce resentment just because demanding implies criticism of addressees and is designed to constrain addressees' response. Inherent to routine requesting is the possibility of addressees accepting or denying the request. A faculty member who requests something from a dean maintains the dean's wiggle room because, other things being equal, the dean can accept or deny the request with impunity; requesting acknowledges the dean's prerogative to accept or deny. If the dean is amenable to persuasion in routine ways, such as requesting, then there is no need to demand. In contrast, a faculty member who demands something from a dean implies a negative judgment about the direction of the 
dean's moral compass, and implies that it cannot be corrected unless the dean accedes to the demands. The dean may resent that demanding both makes him look bad and reduces his wiggle room by pressuring him to accede or look even worse.

In short, demanding implies that the speaker can show that she occupies the substantive and procedural high ground. Her efforts to produce change by using ordinary procedures and routine speech acts such as requesting have failed, so she needs to perform a different speech act to influence addressees to act. She counts on addressees seeing her occupy the high ground, and it is her visibly being in the right that is expected to influence - to generate the persuasive force that routine speech acts such as requesting have not. Consequently, we submit that the central obligation incurred just by demanding is living up to a political, rhetorical norm that power accrued by conspicuously occupying the high ground ought to trump institutional, coercive power. This norm is captured in the aphorism "right makes might," perhaps best known to students of rhetoric in its explicit statement by Abraham Lincoln as he exhorted Republicans at Cooper Union in 1860: "let us have faith that right makes might, and in that faith, let us, to the end, dare to do our duty as we understand it" (Holzer 2004, 284). "Right makes might" is at the center of historical and contemporary rhetorical theorizing that describes rhetoric as a way of mitigating violence - as a counter to the position that "might makes right," or "the idea that it is acceptable for a dominant party or group to maintain power over the dominated by using coercive force" (hooks 2015, 118; Conley 1990; Crosswhite 2013). Demanders demand rather than exercise brute force. Because demanding brings that norm to bear in the situation, both demanders and addressees can be held accountable for living up to it.

How does that normative structure-(1) openly demanding to make visible (a) the intent to influence addressees to accede and (b) incurring an obligation to live up to the norm of right 
makes might — account for why somebody uttering a statement of demand may reasonably expect just that utterance to pressure addressees to accede? The answer involves Burgess' (2015) and Wanzer-Serrano's (2015) insights that demanding communicatively changes the context, generates accountability, and entails risks. Bringing to bear the norm of right makes might redesigns the disagreement space (Jackson 1992, 1998; Jacobs 2006) such that addressees now have two reasons to be influenced. To see what these reasons are, recall the resentment that demanding can occasion. For example, if an employee demands time off without first making a request, a scheduling manager can express resentment with impunity, perhaps by saying, “All you had to do was ask!" Or if an employee demands time off on the two days before a major deadline in order to binge watch a television series, the scheduling manager can express resentment with impunity, perhaps by saying, "It is wrong to leave your colleagues in the lurch for frivolous reasons!" Because demanding implies substantive and procedural criticism of addressees, a speaker who demands undertakes a risk of resentment for unfairly impugning addressees' conduct - for failing to make good on the claim to be in the right. As a result, demanding communicatively creates a context in which, first, addressees can reason that the demander would not risk criticism for unfairly impugning their conduct unless she can show she occupies the high ground. Significantly, because norms that speakers bring to bear in a situation are reciprocal, bringing to bear the norm of right makes might constrains addressees from exercising institutional or coercive power, because doing so would put them at risk of criticism for using strong-arm tactics or abusing their position of authority and for failing to see the rightness of the speaker's position. Consequently, second, demanding communicatively creates a context in which a speaker can reason that addressees will accede to demands in order to avoid criticism for remaining conspicuously in the wrong, or at least give the speaker a fair hearing to 
avoid criticism for not adhering to institutional policies and procedures calling for a fair hearing, or for not changing policies and procedures that preclude a fair hearing. Demanding redesigns a disagreement space such that arguments may be discussed on their merits.

Pressure generated just by demanding is not compulsion. Addressees can ignore or dismiss demands with impunity if they are manifestly unreasonable - if it is apparent that the demander is not substantively in the right. Addressees can also ignore or dismiss demands with impunity if they calculate that they will not be held accountable for refusing or failing to see that they are in the wrong, or that they can use strong-arm tactics with impunity. Persuasive force is grounded in responsibility and accountability, and in some circumstances persons may be held accountable for actions only after some time has passed. Addressees may also be able to dismiss demands with impunity if the demands are accompanied by coercive tactics - if it appears that the demander is not living up to the norm of right makes might. The further demanders step outside the bounds of propriety, the more conspicuously the norm of right makes might is brought to bear in the situation; but the greater risk of criticism for apparent coercing, threatening, impropriety. At the same time, by conspicuously undertaking that risk, demanders generate more visibility and therefore accountability for making good on the obligation to show the rightness of their demands and the shortcomings of conventional modes of communication and the structures in which they occur to produce change.

In sum, we submit the following model of the normative structure of demanding generally.

1. Demanding makes visible the speaker's (a) intent and (b) concomitant obligation to live up to the norm of right makes might.

2. The obligation is reciprocal. Both speaker and addressees can hold each other 
accountable for recognizing and living up to the norm.

3. As a result, demanding creates two reasons for addressees to accede.

a. Addressees can reason that the speaker would not risk criticism for acting unreasonably, inappropriately, and the like unless she could show that her demanding is reasonable, appropriate, and the like — that she is in the right substantively and procedurally.

b. The speaker can reason that addressees will be influenced to accede in order to avoid criticism for ignoring manifestly reasonable calls for change, or for dismissing or silencing in coercive ways somebody who deserves a fair hearingfor conspicuously remaining in the wrong.

The model incorporates Burgess' $(2013,2015)$ insights that demanding must be performed openly and recognizably, implies a claim to occupy the high ground, communicatively changes the context, and entails risks. Further, it hinges on Wanzer-Serrano's (2015) insight that strategies change a scene in a way that generates accountability and therefore persuasive force.

Our analysis of the normative structure of demanding is based on the most basic utterance: "I demand you to $x$." Typically just that utterance does not make presumptions sufficiently conspicuous to pressure addressees to accede. How can ordinary social actors design demands that generate persuasive force? Wanzer-Serrano (2015) has shown how members of the Young Lords Organization and the people of El Barrio did just that by acting in accord with the organization's own democratic procedures and by conspicuously displaying (by setting fire to piles of uncollected garbage in intersections) that they were substantively and procedurally in the right in demanding the sanitation department to collect garbage in El Barrio. In what follows we 
show how another group of marginalized people designed demands that pressured establishment members to accede.

\section{Designing demanding}

Shortly after 5:00 p.m. on Friday, February 4, 1972, C.J. Brune, a senior at the University of Kansas, received an excited phone call. On the other end of the line, Mary Coral, the wife of a KU faculty member, declared, "It's on. Come to the head of the alley. Bring enough clothes for a week and lots of food" (Brune 2012). Brune, Coral and almost twenty other women who called themselves the February Sisters, entered the East Asian Studies building and barricaded the doors. Simultaneously, leaflets notifying the campus community that "Women and Children Are Now Occupying a Building on Campus" hit the streets, and a "Statement of Action" was sent to Chancellor E. L. Chalmers. The statement listed six "non-negotiable demands" including a campus daycare center, the development of a women's studies program, and women's health services. By 10:00 p.m. the Senate Executive Committee was convened and several February Sisters representatives left the occupied building to attend a negotiation session. While the first session was fruitless, a second session ended with SenEx acceding to two demands: the university expressed in writing support for daycare and a health care program ("History" 1972). Satisfied with these results, the February Sisters left the building.

An historian recounts, "After that action, and a few news conferences over the next several weeks, they [the February Sisters] never met again as a group, although many of the participants remained active in other feminist organizations" (Monhollon 2002, 202). The February Sisters are local heroes; their actions are memorialized by a plaque at the site of the building they occupied, and the anniversary of their actions continues to be remembered in the 
local newspaper and on the university campus. Their actions are a well-circumscribed case of serious demanding, so well-suited to illustrating how social actors can design demands that generate persuasive force. How did the February Sisters design demands, and why could they reasonably expect them to pressure administrators to accede?

To answer that question, we analyze both the February Sisters' rhetoric and administrators' responses. The February Sisters' rhetoric comprised a leaflet distributed during the occupation of the campus building to students going to Friday films, a "Statement of Action," a "Position Paper," a "History of the Seizure," a press release, an editorial in the university student newspaper, and their occupation of a campus building. The university's response comprised the minutes of meetings between the university Senate Executive Committee and representatives of the February Sisters, an official university response, and other press coverage quoting administrators. In what follows we show how the February Sisters did more than say, "We demand changes" to attempt to influence administrators to accede. As we have shown, just uttering "We demand changes" implies criticism of addressees' moral compass, implies that the speaker can show that she occupies the moral high ground, and implies that the speaker is counting on her occupation of the high ground to influence addressees rather than coercion, threats, and the like. In what follows we show how the February Sisters designed demands to make conspicuously visible that they were undertaking and discharging an obligation to live up to the norm of "right makes might," so redesigning the context to pressure university administrators to live up to it as well — to accede to demands or at least giving them a fair hearing.

First, the February Sisters openly made demands. In the leaflet distributed during the occupation of the campus building, they wrote, "We are demanding a daycare center for women 
on campus" and "a complete list of demands" is available at the Student Activities Center ("Women and Children" 1972). In the mimeographed "Statement of Action" distributed during the occupation, they listed six "non-negotiable demands" and began each with "We demand" $(1972,1)$. In the "Position Paper" released the night of the occupation they wrote, "We demand control of our own program. We demand that Chalmers not speak on the topic of achieving equity for women" $(1972,2)$.

By openly demanding, the February Sisters repeatedly made visible their intent to influence administrators to accede. Because openly demanding constrained their ability to disclaim the intent to influence by demanding, they communicatively created a context in which they could be held accountable for meeting obligations incurred just by demanding. By demanding the February Sisters took a step outside the bounds of propriety. In fact, the recorder of the minutes of the Senate Executive Committee meeting with representatives of the February Sisters used scare quotes to mark the February Sisters' use of the word "demand": "Chancellor Chalmers cited positive but unpublished progress on several of the 'demands,"” and another university administrator "outlined in detail the University position on the six published 'demands"' ("Minutes" 1972, 4). Likewise, a student critical of the February Sisters who annotated a copy of the February Sisters' position paper underlined the word "demands" and wrote, "Note: demands—not requests" ("Phillip W. Garrett" 1972, 2). Just by demanding the February Sisters incurred an obligation to show that they had good reasons for stepping out of bounds - that they were right to do so and not unfairly impugning administrators' conduct. In other words, they incurred an obligation to live up to the norm that right makes might.

Because undertaking and discharging obligations is the source of persuasive force, ordinarily social actors make special efforts to show they are living up to obligations incurred in 
the performance of a basic illocutionary act such as demanding. How did the February Sisters not just imply but explicitly show that they were procedurally and substantively in the right? First, they displayed grounds that they were procedurally in the right in the "Position Paper" by writing, "The Chancellor has overtly ignored legitimate demands of women at KU for three years" and "Program after program has been met with administrators [sic] ennui if not outright hostility" $(1972,1)$. Likewise, the February Sisters distributed at a table in the Kansas Union a history of their actions that began, "Women have been working for three years through legitimate channels on a number of issues" ("History" 1972, 1). Second, they displayed grounds that they were substantively in the right. In a press statement released to the university information center, the February Sisters referred to "accompanying leaflets" for "reasons for this action" ("Press release" 1972). For example, the "Position Paper" displayed grounds for their demand for on-campus daycare, including the amount and kind of work that women performed at the university, and the "institutionalized discouragement of all women to use their talents and skills in areas outside of domestic duties" ("Position" 1972, 2). Similarly, the February Sisters described the handling of birth control at the university health care center as haphazard and inconsistent: "[d]octors vary according to personal belief, practice, and mood concerning birth control" ("Position" 1972, 4). By displaying that they had good reasons for impugning administrators' conduct, the February Sisters made good on a claim to be in the right.

As they displayed grounds for impugning administrators' conduct, so they displayed that they were counting on conspicuously occupying the high ground to be the source of their power rather than coercion by occupying a campus building. In "A Statement of Action" they wrote that they "feel it [the occupation] is a means of obtaining resources to meet the pressing needs of women" and they do not intend to "damage property or violate laws other than those few central 
to our act. We do not intend to 'substantially obstruct the operation of the University' in any way" $(1972,1)$. Likewise, in a press release they wrote, "Our actions are non-violent, nondestructive, and carried out with the specific intention of showing our strength and solidarity, and of drawing public attention to our pressing needs" ("Press release" 1972; see also "History" 1972, 6, 7; Scott, Pryce, and Franke 1972). In press coverage a sympathetic administrator noted the February Sisters were aware that they risked arrest, expulsion, and loss of parental support: “They didn't want to damage anything and they were careful not to" (Henry 1972). Damaging property would have made them vulnerable to a charge of threat or coercion — of failing to live up to the norm of right makes might.

So far we have shown that the February Sisters (1) openly demanded so visibly (a) displayed their intent to influence administrators to accede and (b) incurred an obligation to live up to the norm of right makes might. They displayed that they were in the right by explicitly stating grounds for substantive and procedural criticisms of administrators. Likewise, they displayed that being in the right was the source of might by toeing a line of propriety as they occupied a campus building and explicitly disclaimed violent tactics. But why could they reasonably expect just those strategies to influence administrators to accede?

The visibility of the obligation created a context in which both the February Sisters and administrators could be held accountable for living up to it; the obligation to live up to the norm of right makes might was reciprocal. The reciprocal nature of the obligation is indicated by administrators bringing it to bear in the situation as well. In the official university position statement they wrote, "To achieve legitimate goals by means which can assure their attainment and acceptance, free discussion, recognition of the rights and responsibilities of all parties involved, and persuasion rather than coercion must be employed" ("Minutes" 1972, 11); and "To 
accede to the demands made on this basis [occupation of the campus building] would be to violate the rights of all other members of the University community and attack the fundamental liberties of free discussion, careful consideration of alternative courses of action in arriving at decisions, and the rule of reason for which the University stands" ("Minutes" 1972, 11). The press directly quoted the university position (e.g., "Women's Lib" 1972; "Sisters Call Off” 1972; "KU Women's Lib" 1972) so both administrators and the February Sisters could be held accountable for acting in accord with the norm.

By visibly, dramatically undertaking and discharging an obligation, incurred just by demanding, to live up to the norm of right makes might, the February Sisters changed the context to create two reasons for administrators to accede. First, administrators could presume the February Sisters would not risk arrest, expulsion, and so on unless they could display that their demands had merit— that they could show that administrators were ignoring oppressive conditions and failing to live up to procedural norms such as "free discussion, recognition of the rights and responsibilities of all parties involved, and persuasion." This reason created just by demanding is an essential part of the normative structure of demanding, without which its persuasive force diminishes or collapses. If speakers can talk with no risk—no responsibility or accountability — then the talk is cheap and can be ignored with impunity.

Certainly administrators recognized that the February Sisters' talk would not appear to be cheap, and in fact tried to undermine its persuasive force - to deny the efficacy of the February Sisters' demanding — by trying to show that they had beat the February Sisters to the substantive and procedural high ground. First, they reported that unpublished progress on some demands was already occurring. In newspaper coverage of the event, the director of university relations and development "said KU may have been at fault for not publicizing its efforts more, as the women 
were unaware of many steps the University had taken and was contemplating" (“'Sisters' End" 1972). Likewise, the "University Position" included statements that "The Senate Executive Committee has been deeply concerned about equal opportunity for women and has been involved in discussions with the Chancellor and other members of the administration and the staff for some months," and "Chancellor Chalmers pointed out that significant action already had been taken on many of the women's demands" and listed them ("Minutes" 1972, 4). Second, administrators explicitly brought to bear the norm of right makes might as they called for "free discussion" of the issues. In short, the value of the February Sisters' talk is indicated by administrators trying to take their positions for themselves.

A second reason for influence created just by demanding is that to avoid criticism for failing to live up to the norm of right makes might, administrators will accede. This part of the normative structure is apparent from the February Sisters' metadiscourse about their demand strategy: "unless Senex gave written commitment to the establishment of a day-care center and the implementation of a health care program for women, [.. .] we would remain in the building until we were removed by force" ("History" 1972, 7). To avoid the "bad publicity" (Lawhorn 2013; Rombeck 2002) of a charge of coercion — of failing to live up to the norm of right makes might—administrators took the demands seriously. Administrators could have called in law enforcement authorities, but then they would have been vulnerable to a charge of coercion. Thus the February Sisters' extraordinary action and risk of criticism on procedural grounds pressured administrators to publicly take responsibility for their actions and engage in more apparently democratic procedures to address their substantive criticisms.

In sum, the February Sisters designed demands using strategies that constrained administrators from ignoring or perfunctorily dismissing them. Just by uttering demands they 
implied that administrators were procedurally and substantively in the wrong, and incurred an obligation to live up to the norm of right makes might. But they did more, as demanders typically need to do in order for demands to generate persuasive force. They displayed grounds for demanding at all and, by occupying a campus building and disclaiming violence, displayed that they were counting on the rightness of their position rather than coercion to influence administrators to accede. They communicatively designed a "normative terrain" (Goodwin 2011, 291) such that administrators could be held accountable for living up to the norm so created a reason — to avoid criticism for coercion — to give the February Sisters' demands serious consideration.

\section{Conclusions}

In short, by (1) openly demanding, the February Sisters made visible their (a) intent and (b) concomitant obligation to live up to the norm of right makes might. Because (2) the obligation was reciprocal, the strategy communicatively changed the scene (3) to create two reasons for administrators to accede. First, (a) administrators could reason that the February Sisters would not risk resentment unless they could show good reasons for staking a claim to the substantive and procedural high ground. Second, (b) the February Sisters could reason that administrators, rather than risk criticism for failing to live up to the norm of right makes might, would accede. The February Sisters' rhetoric was designed to display grounds for presumptions generated just by uttering demands - to show they were in the right procedurally and substantively. Likewise, occupying the campus building and disclaiming violence were designed to display that they were counting on their being in the right- - not coercion — to influence administrators to live up to that same norm and accede, or at least engage in "free discussion." 
Our analysis shows why demanding is a fundamental strategy for resisting oppression. Persuasive effects may not be immediate; social actors may need to demand and engage in other rhetorical activities for days or decades to create conditions in which it becomes increasingly difficult to make sexist, racist, homophobic, and the like remarks, and to turn a blind eye to systemic sexism, racism, homophobia, and the like with impunity. Failed demands may not only serve identitarian desiderata of a more just political culture but also, by bringing to bear the norm of right makes might, reaffirm a fundamental norm of political interaction.

${ }^{1}$ We use "paradigm case" in the sense used by O'Keefe (1982): a case that would elicit widespread agreement that it is an example of some concept, in contrast to a borderline case or an empirically common case.

\section{References}

Aakhus, Mark, and Leon V. Laureij. 2012. "Activity, Materiality, and Creative Struggle in the Communicative Constitution of Organizing: Two Cases of Communication Design Practice.” Language and Dialogue 2 (1): 41-59.

Albin, Tammy, and Sherrie Tucker. 2012, February 4. "Introduction.” February Sisters Speak Out: 40 Years after the Occupation. Lawrence, KS.

Asen, Robert. 2005. "Pluralism, Disagreement, and the Status of Argument in the Public Sphere.” Informal Logic 25 (2): 117-137.

Austin, J. L. 1962. How to Do Things with Words. Cambridge: Harvard University Press. Bowers, John W., Donovan J. Ochs, Richard J. Jensen, and David P. Schulz. 2010. The Rhetoric of Agitation and Control. Long Grove: Waveland Press. 
Brune, C.J. 2012, February 4. Personal narrative. February Sisters Speak Out: 40 Years after the Occupation. Lawrence, KS.

Burgess, Sarah. 2013. "Obscene Demands." Philosophy and Rhetoric 46 (3): 351-59.

Burgess, Sarah K. 2015. "Exposing the Ruins of Law: The Rhetorical Contours of Recognition's Demand." Philosophy and Rhetoric 48 (4): 516-535.

Conley, Thomas M. 1990. Rhetoric in the European Tradition. Chicago: University of Chicago Press.

Crosswhite, James. 2013. Deep Rhetoric: Philosophy, Reason, Violence, Justice, Wisdom. Chicago: University of Chicago Press.

van Eemeren, Frans. H., Bart Garssen, Erik C. W. Krabbe, A. Francisca Snoeck Henkemans, Bart Verheij, and Jean H. M. Wagemans. 2014. Handbook of Argumentation Theory. Dordrecht: Springer.

Enck-Wanzer, Darrel. 2006. "Trashing the System: Social Movement, Intersectional Rhetoric, and Collective Agency in the Young Lords Organization's Garbage Offensive.” Quarterly Journal of Speech 92 (2): 174-201.

---. 2011. "Gender Politics, Democratic Demand and Anti-Essentialism in the New York Young Lords." In Latino/a Discourse in Vernacular Spaces: Somos de Una Voz?, ed. Michelle A. Holling and Bernadette M. Calafell, 59-80. Lanham: Lexington Books. Goodwin, Jean. (2001). “Cicero's Authority." Philosophy and Rhetoric 34 (1): 38-60. ---. 2007. “Argument has No Function.” Informal Logic 27 (1): 69-90.

---. 2011. "Accounting for the Appeal to the Authority of Experts." Argumentation, 25 (3): 28596. 
Gregg, Richard B. 1971. "The Ego-Function of the Rhetoric of Protest." Philosophy and Rhetoric 4 (2): 71-91.

Henry, Judy. 1972, February 17. "February Sisters’ History Related, Demands Probed." University Daily Kansan. February Sisters, Box 1 Chronological Records, 1972-, University of Kansas Student Organizations Records, 1886-, 67/126, Kenneth Spencer Research Library, University of Kansas Libraries.

"A History of the Seizure and Occupation of the East Asian Studies Building by the February Sisters, or What it Takes to Make Men Move.” 1972, February 7. February Sisters, Box 1 Chronological Records, 1972-, University of Kansas Student Organizations Records, 1886-, 67/126, Kenneth Spencer Research Library, University of Kansas Libraries.

Holzer, Harold. 2004. Lincoln at Cooper Union: The Speech that Made Abraham Lincoln President. New York: Simon and Schuster.

hooks, bell. 2015. Feminist Theory: From Margin to Center. New York: Routledge. Innocenti, Beth. 2011. “A Normative Pragmatic Model of Making Fear Appeals.” Philosophy and Rhetoric 44 (3): 273-290.

Innocenti, Beth, and Elizabeth Miller. 2016. “The Persuasive Force of Political Humor.” Journal of Communication 66 (3): 366-385.

Jackson, Sally. 1992. "Virtual Standpoints and the Pragmatics of Conversational Argument." In Argumentation Illuminated, ed. Frans. H. van Eemeren, Rob Grootendorst, Anthony Blair, and Charles A. Willard, 260-69. Amsterdam: SicSat.

---. 1998. “Disputation by Design.” Argumentation 12 (2): 183-98.

Jacobs, Scott. 2000. "Rhetoric and Dialectic from the Standpoint of Normative Pragmatics." Argumentation 14 (3): 261-86. 
---. 2006. "Nonfallacious Rhetorical Strategies: Lyndon Johnson’s Daisy Ad.” Argumentation 20 (4): 421-42.

---. 2016. "Employing and Exploiting the Presumptions of Communication in Argumentation." Informal Logic 36 (2): 159-91.

Kauffeld, Fred. J. 1998. "Presumptions and the Distribution of Argumentative Burdens in Acts of Proposing and Accusing." Argumentation 12 (2): 245-66.

---. 2001. "Argumentation, discourse, and the rationality underlying Grice's analysis of utterance-meaning." In Cognition in Language Use, ed. T. E. T. Németh, 149-163. Antwerp: International Pragmatics Association.

---. 2009. "Grice's Analysis of Utterance-Meaning and Cicero's Catilinarian Apostrophe." Argumentation 23 (2): 239-57.

“KU Women's Lib Calls Off Sit-In.” 1972, February 6. Wichita Eagle, February Sisters, Box 1 Chronological Records, 1972-, University of Kansas Student Organizations Records, 1886-, 67/126, Kenneth Spencer Research Library, University of Kansas Libraries.

Lawhorn, Chad. 2013, September 29. "Longtime Lawrence Activist Recalls 1972 Fight for Women's Rights." Lawrence Journal-World. Retrieved from http://www2.ljworld.com/news/2013/sep/29/longtime-lawrence-activist-recalls-1972-fightwome/

Lundberg, Christian. 2012a. Lacan in Public: Psychoanalysis and the Science of Rhetoric. Tuscaloosa: University of Alabama Press.

---. 2012b. “On Being Bound to Equivalential Chains.” Cultural Studies 26 (2-3): 299-318. 
"Minutes of SenEx." 1972, January 18, 26, 31, February 4. February Sisters, Box 1

Chronological Records, 1972-, University of Kansas Student Organizations Records, 1886-, 67/126, Kenneth Spencer Research Library, University of Kansas Libraries.

Monhollon, Randy. L. 2002. "This is America?”: The Sixties in Lawrence, Kansas. New York: Palgrave.

O'Keefe, Daniel J. 1982. "The Concepts of Argument and Arguing." In Advances in Argumentation Theory and Research, ed. J. Robert Cox and Charles Arthur Willard, 3-23. Carbondale: Southern Illinois University Press.

"Phillip W. Garrett to Chancellor Chalmers." 11 Feb. 1972. February Sisters, Box 1 Chronological Records, 1972-, University of Kansas Student Organizations Records, 1886-, 67/126, Kenneth Spencer Research Library, University of Kansas Libraries.

Pinto, Robert C. 2007. "Burdens of Rejoinder." In Reason Reclaimed: Essays in Honor of J. Anthony Blair and Ralph H. Johnson, ed. Hans V. Hansen and Robert C. Pinto, 75-88. Newport News: Vale.

"Position Paper of the February Sisters." 1972, February 1-6. February Sisters, Box 1 Chronological Records, 1972-, University of Kansas Student Organizations Records, 1886-, 67/126, Kenneth Spencer Research Library, University of Kansas Libraries.

"Press release 9:00.” 1972, February 6. February Sisters, Box 1 Chronological Records, 1972-, University of Kansas Student Organizations Records, 1886-, 67/126, Kenneth Spencer Research Library, University of Kansas Libraries.

Rombeck, Terry. 2002, February 3. “30 Years Later, 'Radicals' Have No Regrets.” Lawrence Journal-World. Retrieved from http://www2.ljworld.com/news/2002/feb/03/30_years_later/ 
“A Statement of Action.” 1972, February 1-6. February Sisters, Box 1 Chronological Records, 1972-, University of Kansas Student Organizations Records, 1886-, 67/126, Kenneth Spencer Research Library, University of Kansas Libraries.

Scott, Peggy, Beverly Pryce, and Anne Franke. 1972, February 18. "Sisters Criticize Kansan." University Daily Kansan, February Sisters, Box 1 Chronological Records, 1972-, University of Kansas Student Organizations Records, 1886-, 67/126, Kenneth Spencer Research Library, University of Kansas Libraries.

"Sisters Call off Sit-In." 1972, February 6. Hutchinson News, February Sisters, Box 1 Chronological Records, 1972-, University of Kansas Student Organizations Records, 1886-, 67/126, Kenneth Spencer Research Library, University of Kansas Libraries.

“'Sisters’ End Sit-in After KU Talks.” 5 Feb. 1972. Lawrence Journal-World, February Sisters, Box 1 Chronological Records, 1972-, University of Kansas Student Organizations Records, 1886-, 67/126, Kenneth Spencer Research Library, University of Kansas Libraries.

Stewart, Charles J., Craig Allen Smith, and Robert E. Denton, Jr. 2007. Persuasion and Social Movements, $5^{\text {th }}$ ed. Long Grove: Waveland Press.

Tracy, Karen. 2010. Challenges of Ordinary Democracy: A Case Study in Deliberation and Dissent. University Park: Pennsylvania State University Press.

Wanzer-Serrano, Darrel. 2015. The New York Young Lords and the Struggle for Liberation. Philadelphia: Temple University Press.

"Women and Children are now Occupying a Building on Campus." 1972. February Sisters, Box 1 Chronological Records, 1972-, University of Kansas Student Organizations Records, 1886, 67/126, Kenneth Spencer Research Library, University of Kansas Libraries. 
“Women’s Lib Group at KU Ends Sit-In.” 1972, February 6. Topeka Capital-Journal, February Sisters, Box 1 Chronological Records, 1972-, University of Kansas Student Organizations Records, 1886-, 67/126, Kenneth Spencer Research Library, University of Kansas Libraries. 